\title{
Comparative Antioxidant Activity on the Ficus benjamina and Annona reticulata Leaves
}

\author{
Nyi Mekar Saptarini ${ }^{1}$, Irma Erika Herawati ${ }^{2}$ \\ ${ }^{1}$ Faculty of Pharmacy, Padjadjaran University, Indonesia \\ ${ }^{2}$ Department of Pharmacy, FMIPA, Al Ghifari University, Indonesia
}

\section{Article Info \\ Article history: \\ Received Dec 12, 2014 \\ Revised Jan 20, 2015 \\ Accepted Feb 06, 2015}

\section{Keyword:}

Annonareticulate

Antioxidant

Extract

Ficusbenjamina

Fraction

\begin{abstract}
Antioxidants can prevent free radical formation. Natural antioxidants found in many plants, such as Ficus benjamina and Annona reticulata. The study aimed to compare the antioxidant activity of extracts and fractions of Ficus benjamina and Annona reticulata leaves against 1,1-diphenyl-2picrilhydrazyl. The steps of this study consist of extraction, fractionation with n-hexane, ethyl acetate and water, phytochemical screening, antioxidant activity determination, and comparing the $\mathrm{IC}_{50}$ values. Percentage scavenging activity of the extracts and fractions against DPPH was calculated to determine the antioxidant activity. The $\mathrm{IC}_{50}$ value of Ficus benjamina was $127.86 \mathrm{ppm}$ for ethanolic extract, $94.01 \mathrm{ppm}$ for water fraction, $115.48 \mathrm{ppm}$ for ethyl acetate fraction, and $335.50 \mathrm{ppm}$ for $\mathrm{n}$-hexane fraction. The $\mathrm{IC}_{50}$ value of Annona reticulata was $274.31 \mathrm{ppm}$ for ethanolic extract, $211.42 \mathrm{ppm}$ for water fraction, $367.91 \mathrm{ppm}$ for ethyl acetate fraction, and $741.08 \mathrm{ppm}$ for n-hexane fraction. The results showed that the Ficus benjamina water fraction was the best antioxidant compared to other extract and fraction.
\end{abstract}

Copyright (C) 2015 Institute of Advanced Engineering and Science. All rights reserved.

\section{Corresponding Author:}

Nyi Mekar Saptarini, Faculty of Pharmacy, Universitas Padjadjaran, Jl Raya Bandung Sumedang km 21, Jatinangor, West Java, Indonesia 45363.

Email: nyi.mekar@unpad.ac.id

\section{INTRODUCTION}

Free radicals defined as chemical species possessing unpaired electrons. These species responsible to many chronic and degenerative diseases including atherosclerosis, ischemic heart disease, ageing, diabetes mellitus, cancer, immunosuppression, neurodegenerative diseases and others [1]-[3]. The most effective compound to eliminate free radicals is antioxidants. Antioxidants prevent free radical formation by scavenging them or promoting their decomposition and suppressing such disorders [4]-[6]. There is a growing interest toward natural antioxidants. The idea of natural antioxidant in herbal resources can protect biology systems from oxidative stress [7]-[9]. Ficus benjamina (Moraceaae) and Annona reticulata (Annonaceae) are herbal resources that had antioxidant activity.

F.benjamina and A. reticulate have been used as traditional medicines. This is due sencondary metabolites. F. benjamina leaves contain tannins, carbohydrates, phytosterols, flavonoids, phenolics, saponins, oils and fats [10],[11]. The root barks, leaves and stems of A.reticulata contain isoquinoline alkaloids and flavonoids [12]. Phenolics, flavonoids, vitamins, and minerals $(\mathrm{Cu}, \mathrm{Mn}, \mathrm{Zn}, \mathrm{Se}$ and $\mathrm{Fe})$ are known as natural antioxidants[13]. This study aimed to compare the antioxidant activity of extracts and fractions of F.benjamina and A. reticulata leaves against 1,1-diphenyl-2-picrilhydrazyl (DPPH). 


\section{RESEARCH METHOD}

\subsection{Materials}

F. benjamina and A. reticulate leaves obtained from Manoko, West Java, Indonesia. All chemicals with analytical grade are DPPH, vitamin $\mathrm{C}$, ether, hydrochloric acid, sulfuric acid, ethanol, amyl alcohol, nhexane, ethyl acetate, ammonia, chloroform, magnesium, Dragendorff and Mayer reagent, iron (III) chloride, gelatin, vanillin, and potassium hydroxide.

\subsection{Samples Preparation}

Simplicia macerated with $70 \%$ ethanol for 3 days. Each day, the solvent changed with the fresh one. All macerat collected and vaporated with rotary rotavapor. Dissolve $10 \mathrm{~g}$ of ethanolic extract with aquadest to obtain $100 \mathrm{~mL}$ solution, then done liquid liquid extraction with n-hexane and ethyl acetate, threetimes for each solvent. All fraction collected and vaporated. Phytochemical screening was conducted to simplicia, extract, and fraction with Fransworth methods[14].

\subsection{Antioxidant Activity Determination}

Dissolve $4 \mathrm{mg}$ of DPPH with $96 \%$ ethanol in $100 \mathrm{~mL}$ volumetric flask $(40 \mu \mathrm{g} / \mathrm{mL})$. Dissolve $5 \mathrm{mg}$ of vitamin $C$ and $50 \mathrm{mg}$ of samples (extract and fraction of $F$. benjamina and A. reticulata) with $96 \%$ ethanol, each in $100 \mathrm{~mL}$ volumetric flask, then diluted the solutions to prior concentration.

The DPPH radical was used for the determination of free radical-scavenging activity of the extracts and fractions. The modified method of Okada and Okada (1998) was employed[15].A portion (2 $\mathrm{mL}) \mathrm{of}$ the different concentrations of extract, fraction or vitamin $\mathrm{C}$, each in tube, was added with $3 \mathrm{~mL}$ of $40 \mu \mathrm{g} / \mathrm{mL}$ DPPH. The mixtures were vortexed and incubated in a dark chamber for $30 \mathrm{~min}$, then the absorbancies were measured at $517 \mathrm{~nm}$ using spectrophotometer (Ray LEIGH). The blank was96\% ethanol in place of sample. Percentage scavenging activity was calculated using this formula:

$\%$ of DPPH inhibition $=[(\mathrm{Ab}-\mathrm{Aa}) / \mathrm{Ab}] \times 100$

Where $\mathrm{Aa}$ and $\mathrm{Ab}$ are the absorbance values of the sample and the blank, respectively. A percent inhibition versus concentration curve was plotted and the concentration of sample required for $50 \%$ inhibition was determined and expressed as $\mathrm{IC}_{50}$ value.

\section{RESULTS AND DISCUSSION}

\subsection{Samples Preparation}

Maceration is a cold extraction method. These methods was conducted to maximal extraction of the entire secondary metabolites in the sample. A. reticulataleaves $(6.94 \%)$ has more soluble secondary metabolites in $70 \%$ ethanol compared to F. Benjamina leaves (5.68\%). Liquid liquid extraction was conducted to seperate the secondary metabolites based on its polarity[16]. Water fraction of F.benjamina and A.reticulata bigger than ethyl acetate and n-hexane fraction (Table 1). We concluded that the majority of secondary metabolites in both samples were the polar secondary metabolites.

Tabel 1. Fraction Rendement

\begin{tabular}{cccc}
\hline Sample & $n$ - Hexane $(\%)$ & Ethyl Acetate $(\%)$ & Water $(\%)$ \\
\hline F. benjamina & 4.66 & 11.92 & 82.00 \\
A. reticulata & 23.60 & 21.98 & 54.00 \\
\hline
\end{tabular}

Table 2. Phytochemical Constituents of F. benjaminaand A. reticulata 


\begin{tabular}{|c|c|c|c|c|c|c|}
\hline Sample & Group & Simplicia & $\begin{array}{c}\text { Ethanolic } \\
\text { Extract }\end{array}$ & $\begin{array}{c}n \text {-Hexane } \\
\text { Fraction }\end{array}$ & $\begin{array}{c}\text { Ethyl Acetate } \\
\text { Fraction }\end{array}$ & $\begin{array}{c}\text { Water } \\
\text { Fraction }\end{array}$ \\
\hline \multirow[t]{8}{*}{ F. benjamina } & Alkaloid & - & - & - & - & - \\
\hline & Polyphenolic & + & + & - & - & + \\
\hline & Tannin & - & - & - & - & - \\
\hline & Saponin & - & - & - & - & - \\
\hline & Quinone & + & + & - & - & + \\
\hline & Flavonoid & + & + & + & + & + \\
\hline & $\begin{array}{l}\text { Monoterpenoid / } \\
\text { sesquiterpenoid }\end{array}$ & + & + & - & - & - \\
\hline & Steroid and triterpenoid & - & - & - & - & - \\
\hline \multirow[t]{8}{*}{ A.reticulata } & Alkaloid & - & - & - & - & - \\
\hline & Polyphenolic & - & - & - & - & - \\
\hline & Tannin & - & - & - & - & - \\
\hline & Saponin & + & + & - & - & + \\
\hline & Quinone & - & - & - & - & - \\
\hline & Flavonoid & + & + & + & + & + \\
\hline & $\begin{array}{l}\text { Monoterpenoid / } \\
\text { sesquiterpenoid }\end{array}$ & - & - & - & - & - \\
\hline & Steroid and triterpenoid & - & - & - & - & - \\
\hline
\end{tabular}

$+=$ detected, $-=$ undetected

Phytochemicals are synthesized by plant for self defense from pathogens and environmental stress. These phytochemicals can also used to cure several diseases. It can be stated that the phytochemicals are the compound that determined the medical potential of any plant. Phytochemical screening with color reaction method was conducted to determine the group of secondary metabolites in the sample. Phytochemical screening showed extract that has the same constituents as simplicia (Table 2). It's mean that maceration with $70 \%$ ethanol can extract all groups of secondary metabolites in simplicia.

All ethanolic extract and fraction of $F$. benjamina and A. reticulata contain flavonoids (Table 2). Jain et al (2013) was found that methanolic extract of F. bejamina leaves had high level of phenolic (4.006 $\mathrm{mg}$ gallic acid equivalence/g) and flavonoids (16.005 $\mathrm{mg}$ quercetin acid equivalence/g) [10]. Flavonoids are the phenolic compounds, which are synthesized by plants due to adaptation in response to biotic and abiotic stresses (infection, water stress, cold stress, and high visible light) [17]. Flavonoids inhibit the oxidation reaction through radical scavenging mechanisms by donating an electron to the unpaired electrons in free radicals. In vitro, flavonoids are potent inhibitor to lipid peroxidation, as acatcher of reactive oxygen or nitrogen species, and also able to inhibit the lipooxygenase and cyclooxygenase activity [18]-[20]. The antioxidant activity of phenolic compounds depend on their molecular structure, based on the availability of phenolic hydrogens, which result in the formation of phenoxyl radicals due to hydrogen donation[21].

\subsection{Antioxidant Activity Determination}

Table 3.Persentage of Inhibition Sample to DPPH Radicals

\begin{tabular}{|c|c|c|c|c|c|c|c|}
\hline \multicolumn{2}{|c|}{ Sample } & \multirow{2}{*}{$\begin{array}{c}\begin{array}{c}\text { Concentration } \\
(\mathrm{ppm})\end{array} \\
40\end{array}$} & \multirow{2}{*}{$\begin{array}{c}\% \\
\text { inhibition } \\
34.82\end{array}$} & \multicolumn{2}{|c|}{ Sample } & \multirow{2}{*}{$\begin{array}{c}\begin{array}{c}\text { Concentration } \\
(\mathrm{ppm})\end{array} \\
100\end{array}$} & \multirow{2}{*}{$\begin{array}{c}\% \\
\text { inhibition } \\
33.40\end{array}$} \\
\hline F. benjamina & Ethanolic & & & \multirow[t]{20}{*}{ A. reticulata } & \multirow{5}{*}{$\begin{array}{c}\text { Ethanolic } \\
\text { extract }\end{array}$} & & \\
\hline & extract & 80 & 38.03 & & & 150 & 34.76 \\
\hline & & 100 & 44.87 & & & 200 & 42.88 \\
\hline & & 120 & 48.71 & & & 250 & 45.14 \\
\hline & & 160 & 56.83 & & & 300 & 54.62 \\
\hline & Water & 40 & 35.04 & & \multirow{5}{*}{$\begin{array}{l}\text { Water } \\
\text { fraction }\end{array}$} & 50 & 31.60 \\
\hline & fraction & 80 & 40.59 & & & 100 & 38.14 \\
\hline & & 100 & 46.15 & & & 150 & 42.66 \\
\hline & & 120 & 53.84 & & & 200 & 44.01 \\
\hline & & 160 & 87.07 & & & 250 & 57.78 \\
\hline & Ethyl & 40 & 32.26 & & \multirow{5}{*}{$\begin{array}{l}\text { Ethyl } \\
\text { acetate } \\
\text { fraction }\end{array}$} & 200 & 29.11 \\
\hline & acetate & 80 & 36.96 & & & 250 & 32.50 \\
\hline & fraction & 100 & 49.78 & & & 300 & 46.27 \\
\hline & & 120 & 55.34 & & & 350 & 48.08 \\
\hline & & 160 & 57.47 & & & 400 & 52.14 \\
\hline & n-hexane & 100 & 17.37 & & \multirow{5}{*}{$\begin{array}{l}\text { n-hexane } \\
\text { fraction }\end{array}$} & 200 & 31.60 \\
\hline & fraction & 150 & 21.09 & & & 300 & 32.50 \\
\hline & & 200 & 21.58 & & & 400 & 39.50 \\
\hline & & 250 & 24.56 & & & 500 & 42.66 \\
\hline & & 300 & 51.86 & & & 600 & 44.01 \\
\hline
\end{tabular}


Natural antioxidants from medicinal plants are a good choice to control oxidative stress. Because of natural origin, these compounds are usually non toxic. Antioxidants upon interaction with DPPH radicals transfer a proton to DPPH radicals by direct abstraction of phenol $\mathrm{H}$ - atoms and electron transfer process, thus neutralizing its free radical character, which produce DPPH-H (2,2-diphenyl-1-picrylhidrazyn), i.e DPPH with less reactivity.The DPPH radicals solution was purple, because the unpaired nitrogen electrons[22]. The absorbance of $40 \mathrm{ppm}$ DPPH radicals solution was 0.443 . These reaction was showed with color alteration from purple to yellow with absorbance reduction at $517 \mathrm{~nm}$. The degree of discolouration indicates the scavenging potential of the antioxidants [23],[24]. Antioxidant activity were measured from reaction of the sample (extracts and fractions) and vitamin C solutions with DPPH solution, then percentage of DPPH inhibition were counted (Table 3). The $\mathrm{IC}_{50}$ value of extracts and fractions werecounted from the linear regression equation of the curve of concentrations versus $\%$ inhibition (Table 4). More smallerthe $\mathrm{IC}_{50}$ value, it'smeanmore higher antioxidant activity. The antioxidant activity was dose dependent manner.

Jain et al (2013) was determined the $\mathrm{IC}_{50}$ value for the methanolic extract of $F$. benjamina leaves was $59.07 \mathrm{ppm}[10]$. Jamkhande et al (2014) was determined the $\mathrm{IC}_{50}$ value for the methanolic extract of $A$. reticulate roots was $108.71 \mathrm{ppm}[25]$. These values lower than our results. These were due to differences in the solvent and the part of the plant which used in extraction, so that the content of secondary metabolites in the extracts was different.

Table4.The $\mathrm{IC}_{50}$ Value of Sample

\begin{tabular}{clcrr}
\hline & Sample & Linear Regression Equation & \multicolumn{1}{c}{$\mathrm{R}^{2}$} & \multicolumn{1}{c}{$\mathrm{IC}_{50}$} \\
\hline \multirow{2}{*}{ F.benjamina } & Ethanolic extract & $\mathrm{y}=0.1918 \mathrm{x}+25.475$ & 0.9638 & 127.86 \\
& Water fraction & $\mathrm{y}=0.4233 \mathrm{x}+10.203$ & 0.8515 & 94.01 \\
& Ethyl acetate fraction & $\mathrm{y}=0.235 \mathrm{x}+22.86$ & 0.8786 & 115.48 \\
& $\mathrm{n}$-hexane fraction & $\mathrm{y}=0.144 \mathrm{x}-1.946$ & 0.6720 & 335.50 \\
A.reticulata & Ethanolic extract & $\mathrm{y}=0.1056 \mathrm{x}+21.032$ & 0.9421 & 274.31 \\
& Water fraction & $\mathrm{y}=0.1165 \mathrm{x}+25.369$ & 0.9090 & 211.42 \\
& Ethyl acetate fraction & $\mathrm{y}=0.1233 \mathrm{x}+4.636$ & 0.9184 & 367.91 \\
& n-hexane fraction & $\mathrm{y}=0.0350 \mathrm{x}+24.062$ & 0.9320 & 741.08 \\
Vitamin C & & $\mathrm{y}=5.3525 \mathrm{x}+12.497$ & 0.9149 & 7.00 \\
\hline
\end{tabular}

Table 4 showed that the $F$. benjamina water fraction has the best antioxidant activity $\left(\mathrm{IC}_{50} 94.01\right.$ ppm) compared to the other extracts and fractions, both $F$. benjamina and A. reticulata. $F$. benjamina water fraction contains polyphenols, quinones, and flavonoids. All these structure having the hydroxyl group which can donate hydrogen to interact with DPPH radical to produce the DPPH-H.A compound is categorized as a very strong antioxidant when the $\mathrm{IC}_{50}$ value is less than $50 \mathrm{ppm}$, strong antioxidant if the $\mathrm{IC}_{50}$ value is $50-100$ ppm, mild antioxidant if the $\mathrm{IC}_{50}$ value is $100-150 \mathrm{ppm}$, and weak antioxidant if the $\mathrm{IC}_{50}$ values is $150-200$ ppm [22]. The F. benjamina water fraction categorized as strong antioxidant. The F. Benjamina ethanolic extract and ethyl acetate fraction categorized as mild antioxidant. The remnants are considered have no antioxidant activity.

The ratio of antioxidant activity ofthe $\mathrm{IC}_{50}$ value of $F$. benjamina and A. reticulate to vitamin $\mathrm{C}$ ( 7 ppm) was determined to compare the sample reactivity to DPPH radicals. The $F$. benjamina water fraction had the best ratio to vitamin $\mathrm{C}$ (Table 5). This means that the $F$. benjamina water fraction was potent antioxidant to be developed.

Table5.TheAntioxidant Activity RatioofF. benjamina and A. reticulatatoVitamin C

\begin{tabular}{cccc}
\hline & Sample & $\mathrm{IC}_{50}(\mathrm{ppm})$ & Ratio \\
\hline F. benjamina & Ethanolic extract & 127.86 & $1: 18.26$ \\
& Water fraction & 94.01 & $1: 13.43$ \\
& Ethyl acetate fraction & 115.48 & $1: 16.49$ \\
n. reticulata & n-hexane fraction & 335.50 & $1: 46.57$ \\
& Ethanolic extract & 274.31 & $1: 39.18$ \\
& Water fraction & 211.42 & $1: 30.20$ \\
& Ethyl acetate fraction & 367.91 & $1: 52.55$ \\
& n-hexane fraction & 741.08 & $1: 105.86$ \\
\hline
\end{tabular}

IJPHS Vol. 4, No. 1, March 2015: $21-26$ 


\section{CONCLUSION}

The extract and fractions of the A. reticulate leaves are considered have no antioxidant activity. In $F$. benjamina leaves, the n-hexane fraction is considered have no antioxidant activity, ethanolic extract and ethyl acetate fraction are categorized as mild antioxidant, and the water fraction is categorized as strong antioxidant.

\section{ACKNOWLEDGEMENTS}

We thank Putri Fajrina Yuda and Rosmiati for their technical support.

\section{REFERENCES}

[1] Metodiewa D., Koska C.,"Reactive oxygen species and reactive nitrogen species: relevance to cyto(neuro)toxic events and neurologic disorders” An overview. Neurotox Res,vol. 1, pp. 197-233, 2000.

[2] Young I., Woodside J.,"Antioxidants in health and disease”, J Clin Pathol,vol. 54, pp. 176-86, 2001.

[3] Heinecke J., "Oxidative stress: new approaches to diagnosis and prognosis in atherosclerosis", Am J Cardiol,vol. 91, pp. 12A-6A, 2003.

[4] Maxwell S.,"Prospects for the use of antioxidant therapies",Drugs,vol. 49, pp. 345-61, 1995.

[5] Kaur C., Kapoor H., "Antioxidant activity and total phenolic content of some Asian vegetables”, Int J Food Sci Tech,vol. 37, pp. 153-62, 2002.

[6] Cesquini M., Torsoni M., Stoppa G., Ogo S.,"t-BuOH-induced oxidative damage in sickle red blood cells and the role of flavonoids", Biomed Pharmacother,vol. 57, pp. 124-9, 2003.

[7] Larson R.,"The antioxidants of higher plants", Phytochem,vol. 27, pp. 969-78, 1988.

[8] Gazzani G., Papetti A., Massolini G., Daglia M.,"Anti- and pro-oxidant activity of water soluble components of some common diet vegetables and the effect of thermal treatment", J Agric Food Chem”,vol. 46, pp. 4118- 22, 1998.

[9] Velioglu Y., Mazza G., Gao L., Oomah B.,“Antioxidant activity and total phenolics in selected fruits, vegetables and grain products”, J Agric Food Chem,vol. 46, pp. 4113-7, 1998

[10] Jain A., Ojha V., Kumar G., Karthik L., Rao K.,"Phytochemical Composition and Antioxidant Activity of Methanolic Extract of Ficus benjamina (Moraceae) Leaves", Research J Pharm and Tech,vol/issue: 6(11), pp. 1184-90, 2003.

[11] Almahy H., Rahmani M., Sukari M., Ali A.,"The chemical constituents of Ficus benjamina Linn. and their biological activities", Pertanika Journal of Science and Technology,vol/issue: 11(1), pp. 73-81, 2003.

[12] Nadkarni K.,"Indian Materia Medica”, Mumbai, India: Popular Prakashan,pp. 12-27, 2002.

[13] Saleh M., Clack S., Woodard B., Deolu-Sobogun S.,"Antioxidant and free radical scavenging activities of essential oils", Ethnicity and Disease,vol/issue: 20(1), pp. S1-78-82, 2010.

[14] Fransworth N.,"Biological and Phytochemycal Screening of Plants",JPharm Sci,vol/issue: 1(5), pp. 247-68, 1966.

[15] Okada Y., Okada M.,"Scavenging effect of soluble proteins in broad beans on free radicals and active oxygen species", J Agric Food Chem,vol. 46, pp. 401-6, 1998.

[16] Houghton P., Raman A.,"Laboratory Handbook for the Fractionation of Natural Extracts", London: Chapman \& Hall, 1998.

[17] Pitchersky E., Gang D.,"Genetics and biochemistry of secondary metabolites in Plants: An evolutionary perspective", Trends Plant Sci,vol. 5, pp. 459-45, 2000.

[18] Gordon M.,"Food antioxidants", In: Hudson B, editor. The mechanism of antioxidant action in vitro. London, NY: Elsevier,pp. 50-80, 1990.

[19] Halliwell B., Gutteridge J., "Free Radical in Biology and Medicine”, New York: Oxford University Press, pp. 2550,2000

[20] Okawa M., Kinjo J., Nohara T., Ono M.,"DPPH (1,1-Diphenyl-2-Picrylhydrazyl) Radical Scavenging Activity of Flavonoids Obtained from Some Medicinal Plants", Biol Pharm Bull,vol/issue: 24(10), pp. 1202-5, 2001.

[21] Ramarathnam N., Ochi H., Takeuchi M.,"Natural Antioxidants; Chemistry, Health Effects and Application", In: Shahidi F, editor. Antioxidant defense system in vegetable extracts. Champaign IL: AOAC Press, pp. 76-87, 1997.

[22] Molyneux P.,"The Use of The Stable Free Radical Diphenylpicrilhydrazyl (DPPH) for Estimating Antioxidant Activity", Songklanakarin J Sci Technol,pp. 211-9, 2004.

[23] Foti M., Daquino C., Geraci C.,"Electron-transfer reaction of cinnamic acids and their methyl esters with the DPPH radical in alcoholic solutions", $J$ of Organic Chemistry,vol/issue: 69(7), pp. 2309-14, 2004.

[24] Villaňo D., Fernández-Pachón M., Moyá M., Troncoso A., García-Parrilla M.,"Radical scavenging ability of polyphenolic compounds towards DPPH free radical", Talanta,vol.71, pp. 230-5, 2007.

[25] Jamkhande P., Wattamwar A., Pekamwar S., Chandak P.,"Antioxidant, antimicrobial activity and in silico PASS prediction of Annona reticulata Linn. root extract", Beni-Suef University J of Basic and Applied Science,vol. 3, pp. 140-8, 2014. 


\section{BIOGRAPHIES OF AUTHORS}

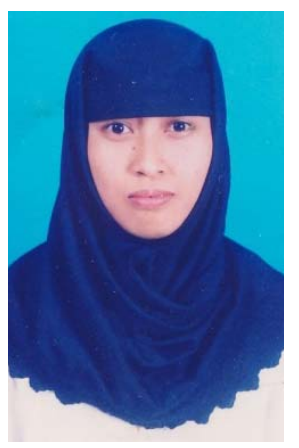

Full name

NIP

Birth

Expertise

Occupation

Affiliation

Office address

Email address



Occupation

Affiliation

Office address

Email address
Nyi Mekar Saptarini

197610162006042001

Pandeglang, 16 Oktober 1976

Pharmaceutical Analysis and Medicinal Chemistry

Lecturer

Faculty of Pharmacy Universitas Padjadjaran

Jl. Raya Bandung-Sumedang Km.21,Jatinangor,West Java, 45363

Telp/Fax : 022-7796200/022-7796200

nyi.mekar@unpad.ac.id

mkrnyi@gmail.com

$\begin{array}{ll}\text { Full name } & \text { Irma Erika Herawati } \\ \text { NIK } & 140090379 / 0.140 \\ \text { Birth } & \text { Bandung 7 Maret 1979 } \\ \text { Expertise } & \text { Biology Pharmacy }\end{array}$

Lecturer

Departement of Pharmacy, FMIPA, Universitas Al-Ghifari

J1. CisarantenKulon No.140 Soekarno-Hatta Bandung, West Java 40293 Telp/Fax : 022-7806223/ 022-7835813 irmaerika@yahoo.com 